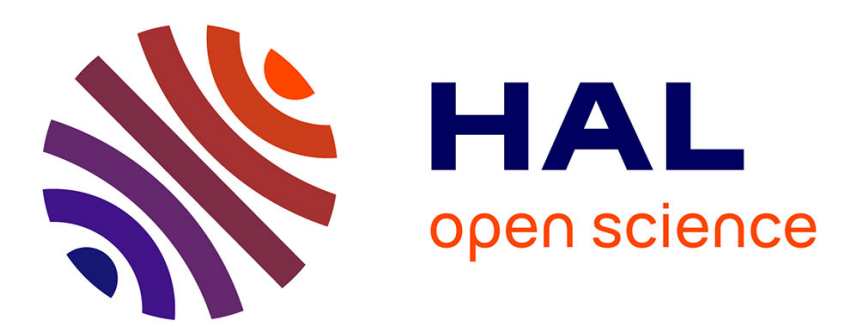

\title{
Electrical cross-talk in transient mode of scanning electrochemical microscopy
}

Dao Trinh, Emmanuel Maisonhaute, Vincent Vivier

\section{To cite this version:}

Dao Trinh, Emmanuel Maisonhaute, Vincent Vivier. Electrical cross-talk in transient mode of scanning electrochemical microscopy. Electrochemistry Communications, 2012, 16 (1), pp.49-52. 10.1016/j.elecom.2012.01.003 . hal-00773615

\section{HAL Id: hal-00773615 https://hal.sorbonne-universite.fr/hal-00773615}

Submitted on 23 Apr 2015

HAL is a multi-disciplinary open access archive for the deposit and dissemination of scientific research documents, whether they are published or not. The documents may come from teaching and research institutions in France or abroad, or from public or private research centers.
L'archive ouverte pluridisciplinaire HAL, est destinée au dépôt et à la diffusion de documents scientifiques de niveau recherche, publiés ou non, émanant des établissements d'enseignement et de recherche français ou étrangers, des laboratoires publics ou privés. 


\title{
Electrical cross-talk in transient mode of scanning electrochemical microscopy
}

\author{
Dao Trinh ${ }^{\mathrm{a}, \mathrm{b}}$, Emmanuel Maisonhaute ${ }^{\mathrm{a}, \mathrm{b}}$, Vincent Vivier ${ }^{\mathrm{a}, \mathrm{b},{ }^{\star}}$ \\ ${ }^{a}$ CNRS, UPR15, Laboratoire Interfaces et Systèmes Electrochimiques, F-75005 Paris, France \\ ${ }^{b}$ UPMC Univ Paris 06, UPR15, LISE, 4 place Jussieu, F-75005 Paris, France \\ * Corresponding authors. \\ V. Vivier Tel.: +33-1-44274158; fax: 33-1-44274074 \\ E-mail address: vincent.vivier@upmc.fr
}

\begin{abstract}
The theoretical and experimental investigations of the electrical cross-talk in a four-electrode configuration without faradaic interference were performed. It was shown that the common resistance shared by the two working electrodes plays a major role in the electrical response of the system. In the particular case of the scanning electrochemical microscopy, the transient response of the probe to a potential step applied to the substrate results in two-time constants and the cell-time constant of the substrate governs the attainable time constant of the whole system.
\end{abstract}

Keywords: SECM, transient electrochemistry, ohmic drop, local potential 


\section{Introduction}

Four-electrode electrochemical systems involving two working electrodes in the same electrochemical cell have been routinely used for a long time [1]. A typical application concerns the rotating ring-disk electrode (RRDE) [2-4] in which a species generated at the disk can be detected at the surrounding disk electrode allowing the study of homogeneous and heterogeneous kinetics $[5,6]$, the determination of diffusion coefficient [3], the investigation corrosion mechanisms [4], and so on. More recently, the scanning electrochemical microscopy (SECM) and derived techniques have considerably broadened the applications, allowing local chemical and electrochemical analyses to be performed [7-11]. The SECM has been widely used in feedback modes that is using a redox mediator in solution for sensing the local reactivity or topography of a sample by measuring a steady-state current at a tip (a micro or a nanoelectrode). In this case, the feedback amplification brings a high sensitivity and indirect temporal resolution [12]. A different mode is the substrate generator / tip collector mode $[13,14]$. Similarly to the RRDE, a species generated at the substrate can be detected at the tip. Whatever the mode used, counter and reference electrodes are usually placed far from the sample under investigation. Then, some common solution resistance is shared by both working electrodes. However, in most cases, the current densities remain low enough so that only diffusionnal cross-talk between them has to be considered [15]. The simplified equivalent electrical scheme depicted in Fig. 1a can qualitatively explain the electrical interactions due to the sharing of common current lines when all potentials are referred to a common reference electrode. This problem has been considered initially for steady-state systems in the case of iron dissolution [16] and then by Brückenstein et al. [17].

In the present context, there is a regain of interest to get a true temporal and as short as possible resolution in four or more electrode systems. For instance, Combellas et al. have used transient SECM for studying the kinetics of polystyrene thin-film etching [18] or for 
electrochemical patterning of PTFE surface [19], whereas Bard et al. have developed the surface interrogation mode to detect and quantify adsorbed species at a substrate [20]. In a recent work, Trinh et al. have developed the SECM in ac-mode (by applying a small sinewave potential perturbation at the substrate) for the characterization of adsorbate intermediates at the substrate electrode $[21,22]$. In that case, only the low frequency domain was investigated since the relevant time-constant was observed for frequency below $100 \mathrm{~Hz}$. However, both capacitive and diffusionnal currents are much higher at short times, so that these interferences need to be considered for studies in the high frequency domain. Transient analysis in SECM experiment was also previously performed by Bard et al. [23] to predict the chronoamperometric response of the tip electrode in presence of a redox couple. However, only the diffusionnal contribution of the electroactive species was taken into account, and the current and potential distributions of the system were neglected. For the later, the quantities of interest are the cell time-constant, which involves the electrolyte resistance and the double layer capacitance and which can be obtained experimentally from transient experiments. In this communication we investigate theoretically and experimentally this electrical cross-talk in the SECM configuration without faradaic interference.

\section{Material and methods}

The electrochemical cell was a four-electrode cell with a platinum grid and a saturated calomel electrode (SCE) that acted as counter electrode and reference electrode, respectively. The substrate was a $2.5 \mathrm{~mm}$ diameter platinum disk embedded in an epoxy resin, and the SECM tip consisted in a $10 \mu \mathrm{m}$ in diameter Pt wire sealed into a glass capillary. A dual microelectrode which consisted in a $20 \mu \mathrm{m}$ in diameter Pt wire and a $40 \mu \mathrm{m}$ in diameter Ag wire was fabricated by sealing the two wires in a glass bi-capillary. Both wires were previously laterally insulated with a cataphoretic paint. The Ag electrode was then anodized 
in a chloride solution to obtain an $\mathrm{Ag} / \mathrm{AgCl}$ micro-reference electrode. The potential variation was monitored by measuring $\mathrm{EAgCl} / \mathrm{Ag}$ vs the grounded $\mathrm{Pt}$ electrode.

Twice-distilled deionized water and pure chemical reagents (analytical grade quality) were used as received for the preparation of the electrolytic solutions.

The SECM used is a home-made device already described elsewhere [24, 25]. The electrochemical workstation is a home-made bi-potentiostat. Small current measurements were performed with a low-noise current-to-voltage converter DLPCA200, BFI Optilas). The entire setup had a negligible rise-time of less than $5 \mu$ s neglected in the simulations. It was controlled by a software developed under Labview ${ }^{\circledR}$. Fast rate acquisitions were performed with a four analog channel oscilloscope (Agilent Technologies - Infiniium DSO9104A).

\section{Theory}

Let us consider the electrochemical system consisting of a four-electrode bipotentiostat that can be described by the simple electrical circuit depicted in Fig. 1a assuming an ideal reference. For simplicity of the analysis only resulting global resistances were taken into account and not the local ones that may differ due to peculiar shape of the equipotentials. In absence of electroactive species, only the double layer capacitance and the electrolyte resistance of each electrode have to be considered. In addition, the counter electrode is assumed to be large, allowing to neglects its charge transfer resistance and capacitance.

The potential of the substrate, $\mathrm{V}_{\mathrm{S}}$, is given by

$$
\mathrm{V}_{\mathrm{S}}=\mathrm{U}_{\mathrm{S}}+\mathrm{U}_{\mathrm{C}}
$$

Similarly, the potential of the probe, $\mathrm{V}_{\mathrm{P}}$, is given by

$$
\mathrm{V}_{\mathrm{P}}=\mathrm{U}_{\mathrm{P}}+\mathrm{U}_{\mathrm{C}}
$$


Initially, the system is at steady-state, and for simplicity, we assume that they are all zero. At $\mathrm{t}=0$, we apply a potential step $\Delta \mathrm{E} \times \mathrm{H}(\mathrm{t})$ (where $\mathrm{H}(\mathrm{t})$ is the Heaviside function) at the substrate. Thus the current flowing through the counter electrode, $\mathrm{i}_{\mathrm{C}}$, is the sum of two contributions

$$
\mathrm{i}_{\mathrm{C}}=\mathrm{i}_{\mathrm{S}}+\mathrm{i}_{\mathrm{P}}
$$

where $i_{P}$ and $i_{S}$ are the currents flowing through the probe and the substrate, respectively.

$$
\begin{aligned}
& \mathrm{U}_{\mathrm{S}}+\mathrm{U}_{\mathrm{C}}=\Delta \mathrm{E} \\
& \mathrm{U}_{\mathrm{P}}+\mathrm{U}_{\mathrm{C}}=0
\end{aligned}
$$

Taking into account (3) and the charge of a capacitor, (4) and (5) can be rewritten as

$$
\begin{aligned}
& \mathrm{R}_{\mathrm{S}} \mathrm{i}_{\mathrm{S}}+\frac{\mathrm{q}_{\mathrm{S}}}{\mathrm{C}_{\mathrm{S}}}+\mathrm{R}_{\mathrm{C}}\left(\mathrm{i}_{\mathrm{S}}+\mathrm{i}_{\mathrm{P}}\right)=\Delta \mathrm{E} \\
& \mathrm{R}_{\mathrm{P}} \mathrm{i}_{\mathrm{P}}+\frac{\mathrm{q}_{\mathrm{P}}}{\mathrm{C}_{\mathrm{P}}}+\mathrm{R}_{\mathrm{C}}\left(\mathrm{i}_{\mathrm{S}}+\mathrm{i}_{\mathrm{P}}\right)=0
\end{aligned}
$$

Introducing the time derivative of charge for both currents:

$$
\begin{aligned}
& \frac{\mathrm{dq}_{\mathrm{S}}}{\mathrm{dt}}+\frac{\mathrm{q}_{\mathrm{S}}}{\left(\mathrm{R}_{\mathrm{S}}+\mathrm{R}_{\mathrm{C}}\right) \mathrm{C}_{\mathrm{S}}}+\frac{\mathrm{R}_{\mathrm{C}}}{\left(\mathrm{R}_{\mathrm{S}}+\mathrm{R}_{\mathrm{C}}\right)} \frac{\mathrm{dq}_{\mathrm{p}}}{\mathrm{dt}}=\frac{\Delta \mathrm{E}}{\left(\mathrm{R}_{\mathrm{S}}+\mathrm{R}_{\mathrm{C}}\right)} \\
& \frac{\mathrm{dq}_{\mathrm{p}}}{\mathrm{dt}}+\frac{\mathrm{q}_{\mathrm{P}}}{\left(\mathrm{R}_{\mathrm{P}}+\mathrm{R}_{\mathrm{C}}\right) \mathrm{C}_{\mathrm{P}}}+\frac{\mathrm{R}_{\mathrm{C}}}{\left(\mathrm{R}_{\mathrm{P}}+\mathrm{R}_{\mathrm{C}}\right)} \frac{\mathrm{dq}_{\mathrm{S}}}{\mathrm{dt}}=0
\end{aligned}
$$

The set of equations (8) and (9) contain a cross-linked term that can be cancelled only when $\mathrm{R}_{\mathrm{C}}=0 \Omega$. In that case, both charging current are obviously independent and follow the usual exponential decay [1]. In a four-electrode system $\mathrm{R}_{\mathrm{C}}$ is different from zero. For a small probe and a large substrate as is often the case in SECM, the coupling term can be neglected in equations (8) and (9), thus $\mathrm{i}_{\mathrm{S}} \approx \mathrm{i}_{\mathrm{C}}$. At short times compared to $\left(\mathrm{R}_{\mathrm{S}}+\mathrm{R}_{\mathrm{C}}\right) \mathrm{C}_{\mathrm{S}}$, 
$\mathrm{i}_{\mathrm{S}} \approx \Delta \mathrm{E} /\left(\mathrm{R}_{\mathrm{S}}+\mathrm{R}_{\mathrm{C}}\right)$, corresponding to a potential jump of $\mathrm{R}_{\mathrm{C}} \Delta \mathrm{E} /\left(\mathrm{R}_{\mathrm{S}}+\mathrm{R}_{\mathrm{C}}\right)$, inducing a charging current for $C_{P}$. Conversely at long times $\mathrm{dq}_{\mathrm{p}} / \mathrm{dt}$ can be neglected so that $\mathrm{q}_{\mathrm{p}}$ follows the potential evolution at the crossroads (noted A in Fig. 1a). Intermediate cases can be solved easily numerically.

\section{Results and discussion}

The transient responses of both the probe and the substrate to a potential step performed at the substrate are shown in Fig. 1b. These calculations where performed for $R_{P}=100 k \Omega, C_{P}=$ $125 \mathrm{pF}, \mathrm{R}_{\mathrm{S}}=500 \Omega, \mathrm{C}_{\mathrm{S}}=7.85 \mu \mathrm{F}, \mathrm{R}_{\mathrm{C}}=200 \Omega$, and a potential step $\Delta \mathrm{E}=100 \mathrm{mV}$. These parameters values are consistent with a large substrate (few $\mathrm{mm}$ in diameter), a microelectrode as a tip and a double layer capacitance of few tens $\mu \mathrm{F} / \mathrm{cm}^{2}$. The response of the substrate is typical of a charging current with a peak intensity of $0.143 \mathrm{~mA}$ (corresponding to $\Delta \mathrm{E} /\left(\mathrm{R}_{\mathrm{S}}+\mathrm{R}_{\mathrm{C}}\right)$ and a time constant $\tau_{\mathrm{S}}=5.49 \mathrm{~ms}$. As expected, the transient response of the microelectrode shows two time constants: at short times (inset in Fig. 1b) a peak intensity of $0.285 \mu \mathrm{A}$ and a time constant of $12.5 \mu \mathrm{s}$ was obtained whereas at long times, a peak intensity of $-0.65 \mathrm{nA}$ and a time constant of $5.49 \mathrm{~ms}$ was determined. These results point out that the long time behavior of the probe is governed by the charging of the substrate and fit perfectly with short and long-time limiting cases described in the previous section and reported in Fig. 1 as symbols.

We performed an experimental illustration in a $10 \mathrm{mM} \mathrm{KCl}$ solution with a Pt probe of $20 \mu \mathrm{m}$ in diameter and a Pt substrate of $0.5 \mathrm{~cm}$ in diameter (Fig. 2). The potential response of the substrate (Fig. 2a) indicates that the potentiostat regulates the applied potential without any problem in the time-scale investigated. The transient obtained at the substrate is in agreement with the size of the electrode and the electrolyte resistivity. The cell time constant is about 
2.5ms. The short-time response of the probe current (Fig. 2c) shows a well defined exponential decay with a time constant of $4.5 \mu$ s. In both cases, the double layer capacitance of the platinum electrodes was about 18 to $20 \mu \mathrm{Fcm}^{-2}$. This experiment confirmed the influence of the common resistance shared by the two electrodes.

To better describe the influence of the potential distribution in solution when a potential step is applied at the substrate, an additional experiment was performed using a dual microelectrode as probe. The first electrode is a platinum microelectrode used as amperometric sensor, whereas the supplementary electrode is an $\mathrm{Ag} / \mathrm{AgCl}$ microelectrode used a local potentiometric sensor for monitoring the local potential variation in the vicinity of the probe (the interelectrode distance was about $50 \mu \mathrm{m}$ ). Figure 3 shows the transient current at the Pt probe recorded as before simultaneously with the potential variation at the $\mathrm{Ag} / \mathrm{AgCl}$ probe located nearby the Pt microelectrode. The transient potential corroborates the two time constants monitored at the probe indicating that the cross-talk observed between the probe and the substrate correspond to the response to the potential step followed by a slower process corresponding to the charging of the substrate. Usually, the use of microelectrode allows diminishing the contribution of the ohmic drop and the double-layer-charging. As demonstrated here, in a four-electrode system with dimension usually encountered in SECM experiments, the influence of the size of the substrate cannot be neglected. As long as stray capacitances do not dominate $C_{p}[26,27]$, there should be an advantage to work with smaller electrodes having smaller capacitances. The higher $\mathrm{R}_{\mathrm{p}}$ would diminish the coupling at short times, while at long times $\mathrm{R}_{\mathrm{C}} \mathrm{C}_{\mathrm{p}}$ is minimised. Such a behavior can be a serious drawback for applications of transient SECM since some process like diffusion can occur in the submillisecond range [23]. Another possibility can consist in decreasing the substrate size down to the probe dimension as performed by Bard et al. for the surface interrogation mode [20]. 
This kind of configuration can also be found in microsystems such as electrochemical microfluidic devices.

\section{Conclusions}

The time constant of the overall experiment is controlled by the size of the larger electrode (usually the substrate). From a practical point of view, one cannot cancel the effect of the common resistance shared by the two currents with a 4-electrode setup. Two time-constants are observed as a transient response to a perturbation applied at the substrate, and the celltime constant of the substrate governs the attainable time constant of the whole system. Future work will consider local current distributions and interferences when diffusion is occurring. Other electrochemical methods such as cyclic voltammetry, impedance spectroscopy, and derived techniques should also display this coupling at high scan rates or frequencies.

\section{Acknowledgements}

We thank D. Rose (LISE - UPR15) for technical help and ANR (project RADE JCJC 0810 01) for financial support. 


\section{References}

[1] A.J. Bard, L.R. Faulkner, Electrochemical Methods: fundamentals and applications, second ed., Wiley-VCH, New-York, 2001.

[2] W.J. Albery, T. Faraday Soc., 62 (1966) 1915-1919.

[3] M.L. Hitchman, W.J. Albery, Electrochim. Acta, 17 (1972) 787-790.

[4] I. Annergren, M. Keddam, H. Takenouti, D. Thierry, Electrochim. Acta, 41 (1996) 11211135.

[5] W.J. Albery, S. Bruckenstein, T. Faraday Soc., 62 (1966) 2596-2606.

[6] W.J. Albery, S. Bruckenstein, T. Faraday Soc., 62 (1966) 1946-1954.

[7] A.J. Bard, F.R.F. Fan, J. Kwak, O. Lev, Anal. Chem., 61 (1989) 132-138.

[8] E.M. Hussien, T. Erichsen, W. Schuhmann, M. Maciejewska, Anal. Bioanal. Chem., 391 (2008) 1773-1782.

[9] P. Sun, F.O. Laforge, M.V. Mirkin, Phys. Chem. Chem. Phys., 9 (2007) 802-823.

[10] M.A. Edwards, S. Martin, A.L. Whitworth, J.V. Macpherson, P.R. Unwin, Physiol Meas, 27 (2006) R63-108.

[11] E.N. Ervin, H.S. White, L.A. Baker, Anal. Chem., 77 (2005) 5564-5569.

[12] F.O. Laforge, J. Velmurugan, Y. Wang, M.V. Mirkin, Anal.Chem., 81 (2009) 31433150 .

[13] N. Baltes, L. Thouin, C. Amatore, J. Heinze, Angew. Chem. Int. Edit., 43 (2004) 14311435.

[14] C. Amatore, S. Szunerits, L. Thouin, Electrochem. Commun., 2 (2000) 248-253.

[15] A.J. Bard, J.A. Crayston, G.P. Kittlesen, S.T. Varco, M.S. Wrighton, Anal. Chem., 58 (1986) 2321-2331.

[16] C. Gabrielli, M. Keddam, H. Takenouti, J. Chim. Phys. PCB, 69 (1972) 737-740.

[17] S. Bruckenstein, K. Tokuda, W.J. Albery, J. Chem. Soc., Farad T 1, 73 (1977) 823-829.

[18] N. Ktari, C. Combellas, F. Kanoufi, J. Phys. Chem. C, 115 (2011) 17891-17897.

[19] F. Deiss, C. Combellas, C. Fretigny, N. Sojic, F. Kanoufi, Anal.Chem., 82 (2010) 51695175 .

[20] Q. Wang, J. Rodriguez-Lopez, A.J. Bard, J. Am. Chem. Soc., 131 (2009) 17046-17047.

[21] D. Trinh, M. Keddam, X.R. Novoa, V. Vivier, ChemPhysChem, 12 (2011) 2169-2176.

[22] D. Trinh, M. Keddam, X.R. Novoa, V. Vivier, ChemPhysChem, 12 (2011) 2177-2183.

[23] A.J. Bard, G. Denuault, R.A. Friesner, B.C. Dornblaser, L.S. Tuckerman, Anal. Chem., 63 (1991) 1282-1288.

[24] C. Gabrielli, F. Huet, M. Keddam, P. Rousseau, V. Vivier, J. Phys. Chem. B, 108 (2004) $11620-11626$.

[25] C. Gabrielli, M. Keddam, N. Portail, P. Rousseau, H. Takenouti, V. Vivier, J. Phys. Chem. B, 110 (2006) 20478-20485.

[26] J.J. Watkins, J. Chen, H.S. White, H.D. Abruna, E. Maisonhaute, C. Amatore, Anal Chem, 75 (2003) 3962-3971.

[27] C. Amatore, E. Maisonhaute, Anal. Chem., 77 (2005) 303A-311A. 
Figure 1: Electrical equivalent circuit for a four-electrode SECM configuration (a), and simulated transient at the substrate and at the probe (b). Calculations where performed for $\mathrm{R}_{\mathrm{P}}$ $=100 \mathrm{k} \Omega, \mathrm{C}_{\mathrm{P}}=125 \mathrm{pF}, \mathrm{R}_{\mathrm{S}}=500 \Omega, \mathrm{C}_{\mathrm{S}}=7.85 \mu \mathrm{F}, \mathrm{R}_{\mathrm{C}}=200 \Omega$, and a potential step $\Delta \mathrm{E}=$ $100 \mathrm{mV}$. The inset shows the short-time behavior of the probe. Symbols correspond to the limit cases analysis (see text).
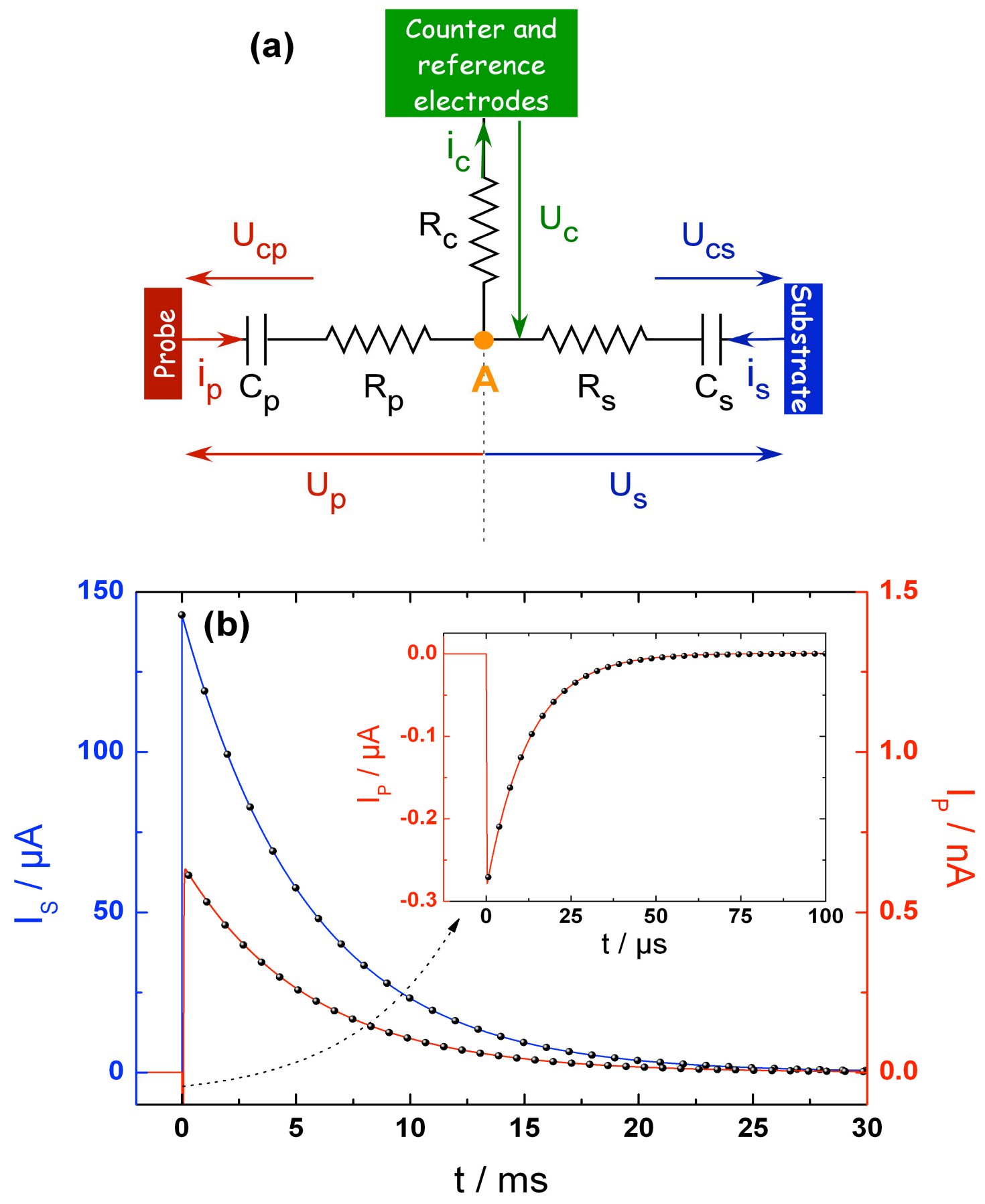
Figure 2: Transient experiment performed with a SECM in a four-electrode configuration. Initially, the probe and the substrate were biased at $0 \mathrm{~V} / \mathrm{SCE}$, and a potential step $(+100 \mathrm{mV})$ was applied to the substrate at $t=0$ s. Potential response of the substrate (a), transient current at the substrate (b) and at the probe for short (c) and long (d) times. Tip-to-substrate distance $\mathrm{d}=10 \mu \mathrm{m}$.
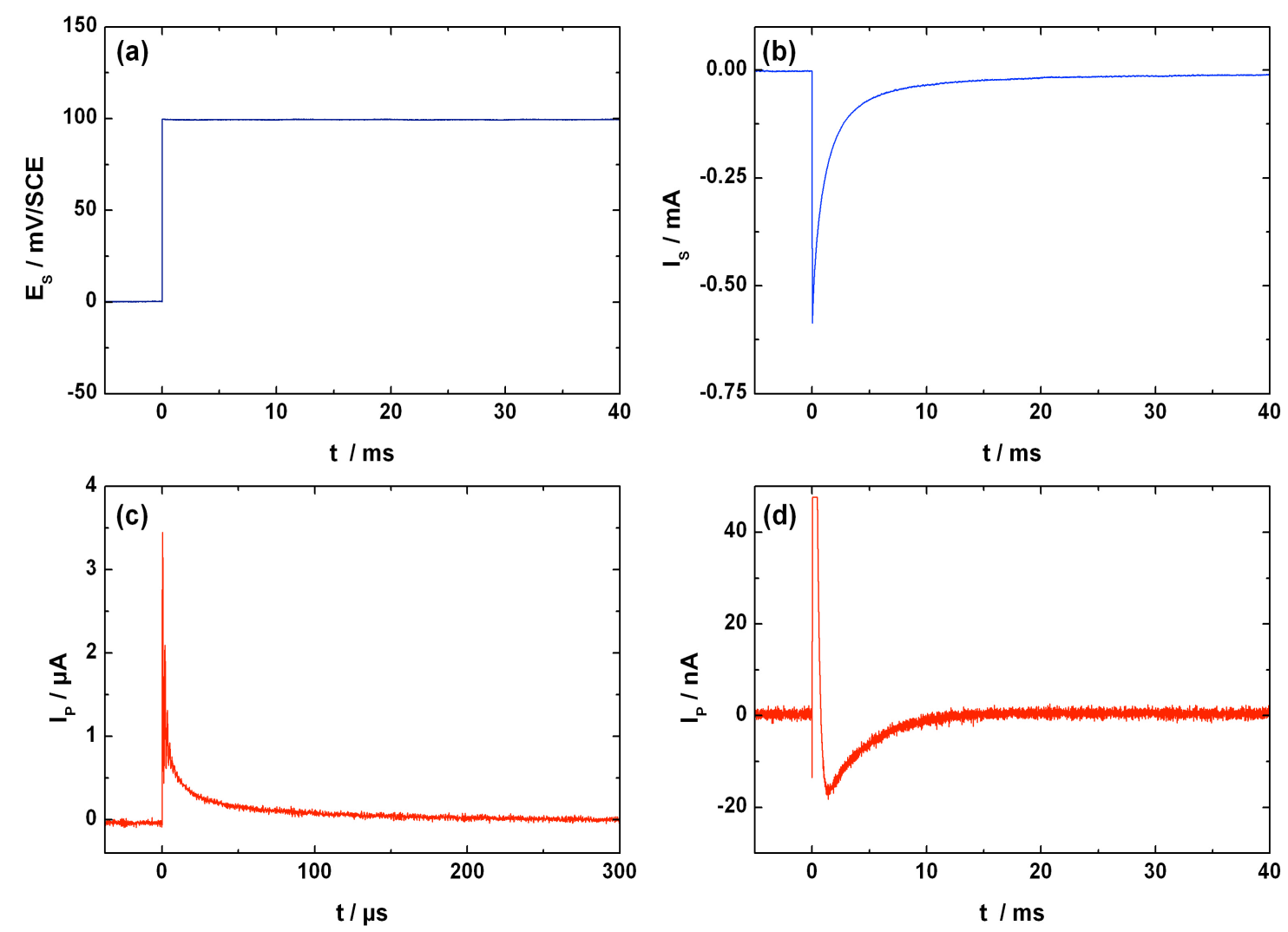
Figure 3: Transient experiment performed with a SECM in a four-electrode configuration with a bi-microelectrode as tip. Initially, the probe and the substrate were biased at $0 \mathrm{~V} / \mathrm{SCE}$, and a potential step $(+200 \mathrm{mV})$ was applied to the substrate at $t=0$ s. Transient current at the probe (a) and local potential variation monitored with the second electrode close to the probe (b) - the inset represent the long time behavior. Tip-to-substrate distance $\mathrm{d}=20 \mu \mathrm{m}$.

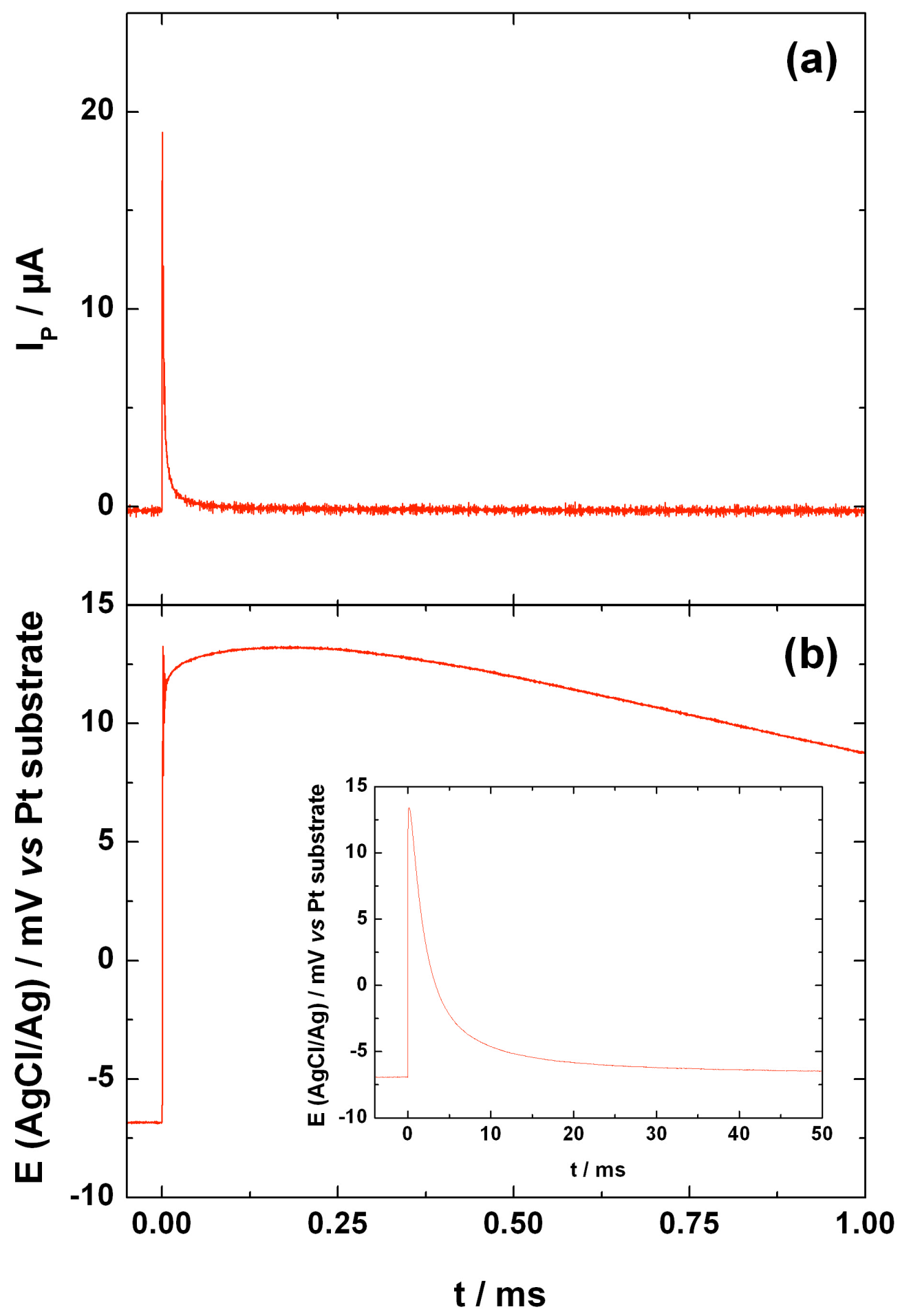

